\title{
Solar Based High Gain Power Converter with Efficient Controller for LED Application
}

\author{
Pydikalva Padmavathi, Sudhakar Natarajan,
}

\begin{abstract}
The representation of this paper is a different approach to get efficient high brightness of LED lighting operating with high gain buck boost converter controlled by efficient incremental conductance MPPT controller algorithm of solar PV module. The mathematical modeling associated with process of simulation for solar panel, high gain buck boost topology and efficient MPPT controller is discussed clearly in this paper. Conventional converters are applied and analyzed for the LED lighting system in literature, but these are not preferred due to lack of efficient performance, high harmonic distortion and low power factor. The projected buck-boost structure is modified structure of high gain buck-boost structure. The comparison between projected converter and existing power converter is clearly summarized in this paper. The switching as well as conduction losses are very low due to single switch operating without transformer. The cost of the solar based LED lighting system with high conversion ratio buck-coost converter is very cheap because the number of semiconductor devices and passive components are using low. In this paper $120 \mathrm{~W}$ and $30 \mathrm{~W}$ of LED lighting system is planned and executed in MATLAB/SIMULINK. The clear summary of outcomes will prove the system is efficient.

Keywords : Solar PV panel, High Gain, Buck-Boost topology, Incremental, LED Lighting Load.
\end{abstract}

\section{INTRODUCTION}

$\mathrm{N}$ owadays the rapid growth with advancing technology is the solar energy to produce the electricity without producing harmful gases which pollutes the environment. Exhaustion of fossil fuel, increases it cost and the gases released by these fuels are dangerous to the environment. So the public turn into renewable energy sources like biomass, biofuel, geothermal, hydro, wind, tidal, solar power generation etc.,. The energy produced by the solar is clean and can be used for different applications [1]-[2]. The solar electrical energy is produced from the solar cells is known as photovoltaic system. Silicone is one of the materials to make these semiconductor materials and they can produce the electrical energy in all circumstances of the sun. If the weather is cloudy then also the cells able to generate the

Revised Manuscript Received on October 30, 2019

* Correspondence Author

Pydikalva Padmavathi, School of Electrical Engineering, Vellore Institute of Technology, Deemed university, Vellore, Tamilnadu, India. Email: p.padmavathi241@gmail.com

Sudhakar Natarajan*, School of Electrical Engineering, Vellore Institute of Technology, Deemed university, Vellore, Tamilnadu, India. Email: nsudhakar@vit.ac.in

(C) The Authors. Published by Blue Eyes Intelligence Engineering and Sciences Publication (BEIESP). This is an open access article under the CC BY-NC-ND license (http://creativecommons.org/licenses/by-nc-nd/4.0/) electrical power by emitting the sun radiation. The voltage at load side of the solar panel is varied due to continuous changes in temperature and irradiation. Due to large fluctuations in output voltage then these are not chosen to connect directly for LED lighting applications [6]. Hence, solar panels must be associated to the LED lighting applications through the power converter in order to meet the load specifications. Solar LED lighting systems is considered an efficient lighting and increasing demand day by day due to its higher lifespan, color rendering, low power consumption, low heat dissipation and safety [5]. Lighting is one the important application because $25 \%$ of generated electrical energy is being consumed in all over the world [4]. LED (Light Emitting Diode) is one of the electronic circuit element which produces the light. LEDs have low consumption of energy, size in small, longer lifespan, durability and several advantages compared to conventional light sources [7]. LED's require forward voltage $\left(\mathrm{V}_{\mathrm{F}}\right)$ and forward current $\left(\mathrm{I}_{\mathrm{F}}\right)$ rating of 1.2 to 3.6 Volts and 10 to $30 \mathrm{~mA}$ to operate exactly at conduction point. The conduction values of $V_{F}$ and $I_{F}$ are varies depending upon the material used for different colors [8]. The light is produced for LED in red color is $1.2 \mathrm{~V}$ and for blue LED is $3.6 \mathrm{~V}$. LED mostly depends on current devices; small variation in voltage leads to produce the large values of currents then the LEDs goes damage. DC-DC converter plays an vital role in solar LED lighting. Normally solar cells produce electrical energy is variable due fluctuations in temperature and irradiation, so the power converter controls by the MPPT algorithm to maintain constant output power to be maximum will be supplied to the LED load. In this situations selection of efficient MPPT control algorithm and power converter is unique one from the best solution to track constant extreme output power at different operating conditions with efficient performance. Continuous changes in irradiation and temperature of the cell will give variable operating point of the array as shown in fig.1. Hence, constant optimal point of the array has been found through the calculation of model or by a search algorithm. There are dissimilar categories of MPPT control procedures have been developed in the cited works [9]-[12]. Perturb and Observe algorithm is the most popular method of tracing the MPP. This control algorithm has some disadvantages as described in [13], which $\mathrm{P} \& \mathrm{O}$ algorithm does not have ability to compare the terminal voltage value of the array with actual operating value of voltage at maximum power point [14]. In this study, selection of MPPT Incremental Conductance control algorithm is the finest resolution because it is easier to appliance, more efficient, higher speed of tracking. 
While coming to the selection of power converter, traditional converters are applied as power electronic interface for LED lighting application [15], where the performance is very poor and several disadvantages are stick with this system as follows. H.C.Shu, Y.P Hsieh et.al proposed flyback topology with reduced value of duty cycle to generate suitable voltage and high efficiency, where voltage gain has been increased with increasing parallelly transformer turns ratio [16]-[17].The high value of turns ratio will gives high spikes in voltages across the semiconductor devices automatically efficiency is decreased. K.I.Hwu et.al high gain voltage power structures with coupled inductor are discussed; Due to leakage inductance released by coupled inductor will adds the voltage stress [18-19]. T.-J.Liang et.al proposed bidirectional converter, where this structure has five numbers of switches that will raises the cost and losses at conducting state [20]. T.J.Peng et.al designed KY converter based on the buck-boost configuration, this converter has two switches [21]. Hence, to overcome from these drawbacks an efficient buck-boost structure with high conversion ratio has been introduced in this study. However, above listed configurations are analyzed by accumulating extra apparatuses to the conventional structures.

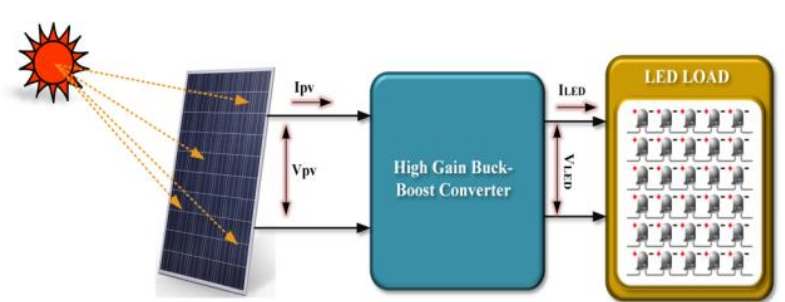

Fig. 1 Block diagram of high voltage conversion ratio buck-boost structure for solar LED lighting system without MPPT Controller

In this study, a high gain topology with humble adjustment in the existing structure. The primary objective of the projected work is to model high gain buck boost topology with an efficient MPPT controller, which is extra effective power conversion with minimized losses, related with conventional structure and be appropriate for achieving the necessities of Solar LED lighting applications. The block diagram of solar based LED lighting system without MPPT controller of high gain buck-boost configuration is as revealed in Fig.1.The basic power conversion work flow of the LED lighting system can be clearly described as follows; the energy radiation coming from the sun is directly absorbed by the solar PV panel. This heat energy converted into electrical energy by using photoconductive materials. Then converted electrical energy is provided to the LED light load through the projected high gain buck-boost structure. The converter controlled by INC algorithm to maintain constant determined power at operating point.

\section{SOLAR PV PANEL MODEL}

The basic device of the PV panel is PV cell. Photovoltaic cell is one of the diode whose light exposed from the $p$-n junction. The operational of a PV cell is established on the standard of photoelectric effect, which is defined as a phenomenon that the emission of the electrons when the light falls on the surface of the material. The free electrons move in the electric field of PV cells that can produces the voltage and current. The current and voltage offered at the depots of PV
Panel could directly associate with the loads such as DC motor applications. But further classy presentations like LED Lighting require dc-dc converters to develop the energy from the PV device. These power converters could regulate the current and voltage at the load. The scientific modeling of PV cell is essential for understanding the performance under different atmospheric conditions. The corresponding circuit of solar PV cell is as exposed in Fig.2.

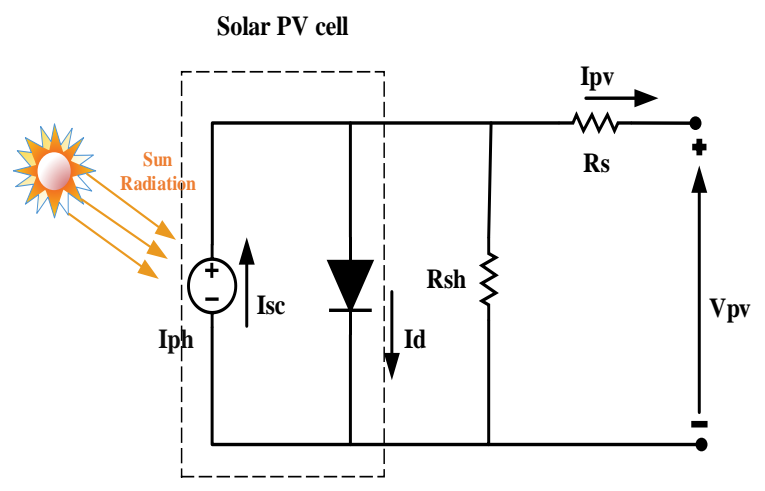

Fig. 2(a) Solar cell equivalent circuit

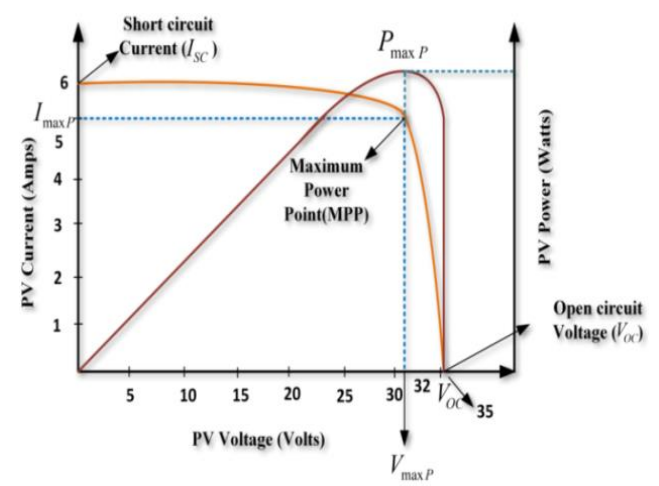

Fig. 2(b) Characteristics of Solar Cell

Consider an ideal diode with shunt and series resistances then the characteristics of voltage and current may be described [22] as follows.

Applying Kirchhoff law

$I_{p v}=I_{p h}-I_{d}-I_{s h}$

The diode current $I_{d}$ is given by

$I_{d}=I_{s}\left(e^{\frac{q\left(V_{p v}+R_{s} I_{p v}\right)}{m k T}}-1\right)$

And the current in the shunt resistance is $\mathrm{I}_{\mathrm{sh}}$ is

$I_{s h}=\frac{V_{p v}+R_{s} I_{p v}}{R_{s h}}$

(3)

The relationship between the solar PV cell and terminal voltage according to the equivalent circuit model is described by the following equation [23]-[24]. 
$I_{p v}=I_{p h}-I_{s}\left(e^{\frac{q\left(V_{p v}+R_{s} I_{p v}\right)}{m k T}}-1\right)-\frac{V_{p v}+R_{s} I_{p v}}{R_{s h}}$

Where

$\mathrm{q}=$ Electron Charge $=1.6021 \times 10^{-19} \mathrm{C}$

$\mathrm{T}=$ Kelvin operating temperature

$\mathrm{K}=$ Boltzmann Constant $=1.3865 \times 10^{-23} \mathrm{~J} / \mathrm{k}$

$\mathrm{I}_{\mathrm{ph}}=$ Photo current (Amps)

$\mathrm{I}_{\mathrm{s}}=$ Saturation current of the diode (Amps)

$\mathrm{R}_{\mathrm{s}}=$ Resistance connected in $\operatorname{series}(\Omega)$

$\mathrm{R}_{\text {sh }}=$ Resistance connected in $\operatorname{shunt}(\Omega)$

$\mathrm{m}=$ Diode factor $(1 \leq \mathrm{n} \leq 2)$

The quantity of solar PV cells is joined in series to arrange a string. The number of strings connected in parallel is called module of PV.

$I=I_{O} \times N_{p} \times I_{p h}-N_{p} \times\left[e^{\left(\frac{V / N_{S}+I \times{ }^{R} / / N_{\mathrm{P}}}{m \times V_{t}}\right)}-1\right]-I_{s h}$

$I_{s h}=\frac{V \times N_{p} / N_{S}+I \times R_{S}}{R_{s h}}$

Where $\mathrm{N}_{\mathrm{p}} \& \mathrm{~N}_{\mathrm{S}}$ are the numeral of parallel and series connected PV modules.

\section{STRUCTURE OF EXISTING CONVERTER AND PROPOSED CONVERTER}

The variation in designed converter to the existing topology is clearly presented and analyzed in this paper. The existing converter consisting of two power switches, two of each inductors, capacitors diodes as shown in fig.3(a)[25]. The voltage is lifting by using the combination of inductor, capacitor and diode. The voltage stress of the active switches is very high and paralelly the number of switches also increasing in order to raise the gain voltage. So, in direction to escape from the shortcomings of this existing topology simple modification is applying for the existing converter that the same concept is applying here to propose new structure with single power switch.

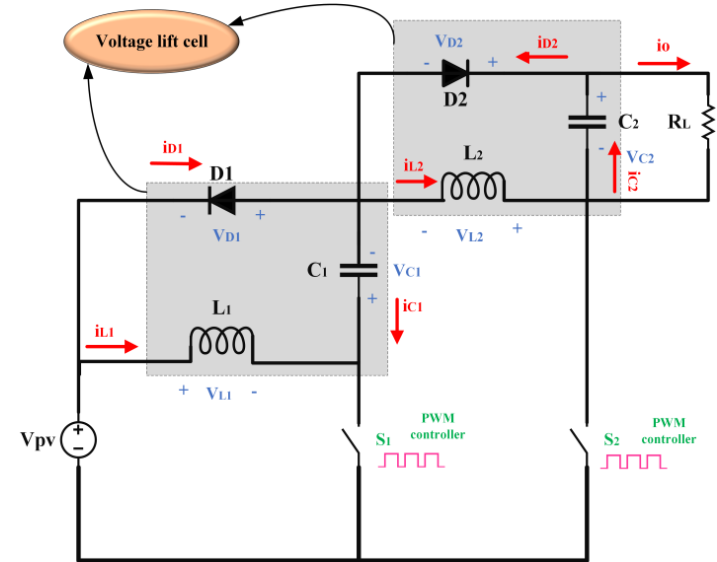

Fig. 3(a) Existing High Gain Buck-Boost Converter

The gain voltage can rise with the combinations of capacitor, inductor, and diode but controlled by the single power switch. The maximum stress voltage of the all devices in the modified configuration is originated to be less related to the proposed converter. The comparison of the both converters resolves based on efficiency, stress voltage, reliability and volume. The proposed structure is designed as a high gain buck-boost converter with easy adjustment in the conventional structure. The designed structure is high efficient compared to the existing converter with much reduced losses and suitable for the solar LED lighting applications.

For solar powered LED lighting system modeling selection of power converter is essential. The main and important factors which influence the chosen of converter are circuit complexity, controller of the converter, availability of the sensors and performance of solar PV panel etc., By considering all key constraints for this lighting system high gain buck-boost structure is designed. Fig 3(a) and 3(b) presents the conventional high voltage gain buck-boost configuration and modified high voltage conversion ratio buck-boost configuration as novel topology respectively. The modification made in the existing high gain buck-boost converter is the removal of one switch and adding required passive components. The planned high gain buck-boost converter is shown in Fig.3(b). This structure having single switch ' $\mathrm{S}$ ', the energy storage elements $\mathrm{L}_{1}, \mathrm{~L}_{2}, \mathrm{~L}_{3}, \mathrm{C}_{1}, \mathrm{C}_{2}, \mathrm{C}_{3}, \mathrm{C}_{4}, \mathrm{C}_{0}$ respectively \& LED load. The analysis of the converter is to be easier by assuming necessary conditions.

They are

1. The configuration can be functioned in CCM. This mode is distributed into two operation modes and its investigation is clearly described.

2. The capacitors of the projected converter are big value and supposing that voltage across the capacitors to be constant.

3. The switch of the projected configuration is considered as ideal and assumes there is no parasitic capacitance for the main switch.

\section{A. Operation modes of the proposed converter}

Mode-I ( $\left.\mathbf{t}_{\mathbf{0}} \leq \mathbf{t} \leq \mathbf{t}_{\mathbf{1}}\right)$ : The steady state wave forms during this time interval mentioned between $\left(\mathrm{t}_{\mathrm{o}} \leq \mathrm{t} \leq \mathrm{t}_{1}\right)$ as displayed in Fig.4. When the switch is going in to conduction mode the three diodes $\mathrm{D}_{1}, \mathrm{D}_{2}$, and $\mathrm{D}_{3}$ are automatically goes turnoff and the equivalent circuit is revealed in fig 3(c). The energy storage elements $L_{1}, L_{2}, L_{3}$ are magnetized linearly and due to capacitors $\mathrm{C}_{2}, \mathrm{C}_{3}$ the capacitors $\mathrm{C}_{1}, \mathrm{C}_{4}$ are charged. The corresponding mathematical expressions can be expressed as follows.

$L_{1} \frac{d i_{L 1}}{d t}=V_{p v}$

(7)

$L_{2} \frac{d i_{L 2}}{d t}=V_{C 2}-V_{C 1}+V_{p v}$

(8)

$L_{3} \frac{d i_{L 3}}{d t}=V_{C 3}-V_{C 4}+V_{p v}$

The average current flowing in the capacitors $\mathrm{C}_{1}, \mathrm{C}_{2}, \mathrm{C}_{3}, \mathrm{C}_{4}$, $\mathrm{C}_{\mathrm{o}}$ through the switch is $\mathrm{ON}$ position. $\mathrm{I}_{\mathrm{C} 1}, \mathrm{I}_{\mathrm{C} 2}, \mathrm{I}_{\mathrm{C} 3}, \mathrm{I}_{\mathrm{C} 4}, \mathrm{I}_{\mathrm{Co}}$ can be achieved as monitors:

$$
I_{C 1}=C_{1} \frac{d V_{C 1}}{d t}=I_{L 2}
$$




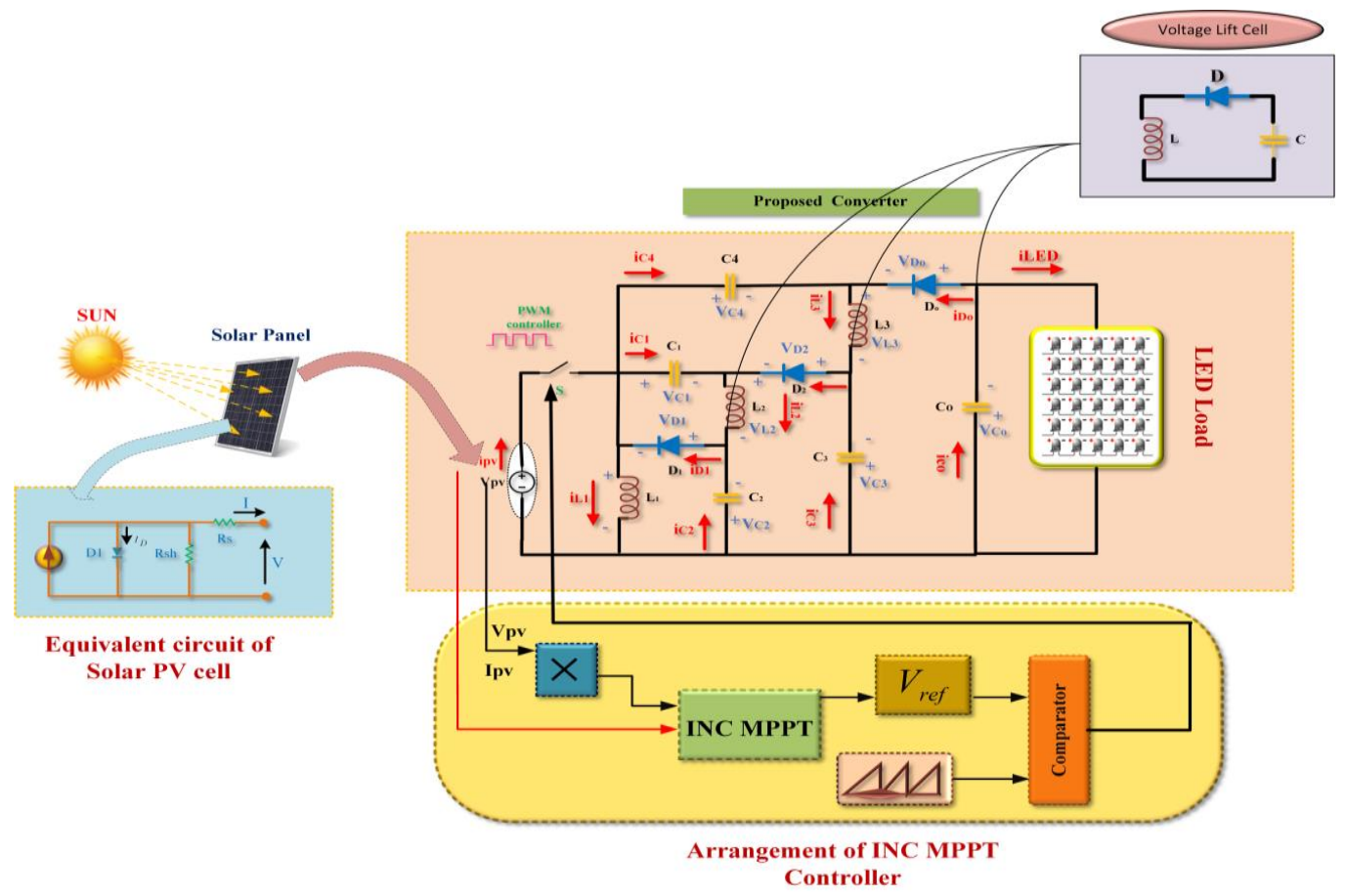

Fig. 3(b) Proposed High Gain Buck-Boost Converter for Solar LED applications with efficient MPPT Controller

$$
\begin{gathered}
-I_{C 2}=-C_{2} \frac{d V_{C 2}}{d t}=I_{L 2} \\
-I_{C 3}=-C_{3} \frac{d V_{C 3}}{d t}=I_{L 3} \\
I_{C 4}=C_{4} \frac{d V_{C 4}}{d t}=I_{L 3} \\
I_{C o}=C_{o} \frac{d V_{C o}}{d t}=-I_{o}
\end{gathered}
$$

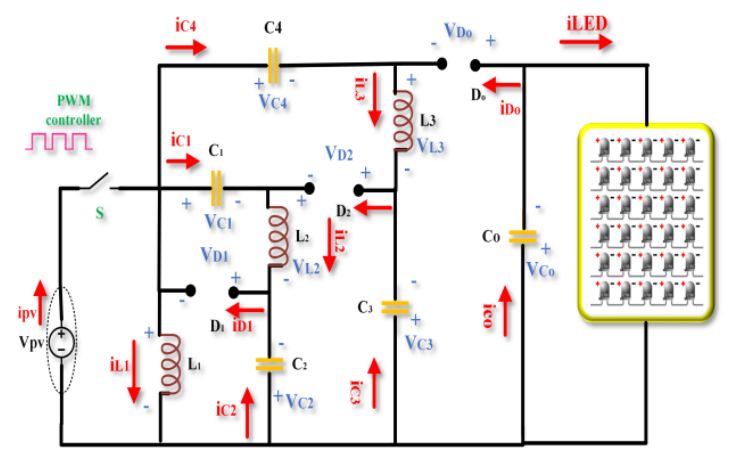

Fig. 3(c) Mode I $\left(t_{0} \leq t \leq t_{1}\right)$

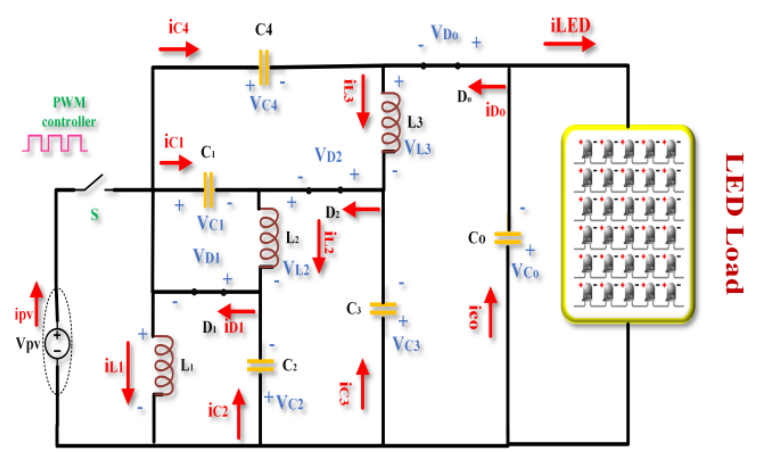

Fig. 3(d) Mode II (t1 $\leq \mathrm{t} \leq \mathrm{t} 2)$

Mode-II ( $\left.\mathbf{t}_{\mathbf{1}} \leq \mathbf{t} \leq \mathbf{t}_{\mathbf{2}}\right)$ : The waveforms for the period of the interval of time $\left(\mathrm{t}_{1} \leq \mathrm{t} \leq \mathrm{t}_{2}\right)$ as shown in Fig.4. When switch is in OFF position the diodes becomes turned on $\mathrm{D}_{1}, \mathrm{D}_{2}$, and $\mathrm{D}_{3}$ correspondingly and the equivalent circuit as displayed in fig.3(d). The energy storage elements $L_{1}, L_{2}$, and $L_{3}$ are demagnetized linearly, due to inductor $\mathrm{L}_{1}$ the capacitor $\mathrm{C}_{2}$, the capacitor $C_{3}$ is receiving charge by the inductors both $L_{1}, L_{2}$ and at the same time the capacitors discharged $\mathrm{C}_{1}, \mathrm{C}_{4}$ respectively. The related equations are given as follows.

$L_{1} \frac{d i_{L 1}}{d t}=-V_{C 2}$

$L_{2} \frac{d i_{L 2}}{d t}=-V_{C 1}=V_{C 2}-V_{C 3}$

$L_{3} \frac{d i_{L 3}}{d t}=V_{C 1}-V_{C 4}=V_{C 3}-V_{O}$

The average current flowing in the capacitors $C_{1}$ and $C_{4}$ through the switch is in OFF position. The current $\mathrm{I}_{\mathrm{C} 1}, \mathrm{I}_{\mathrm{C} 4}$ are representing as follows.

$I_{C 1}=C_{1} \frac{d V_{C 1}}{d t}=I_{L 2}-I_{C 3}-I_{L 3}$

$I_{C 4}=C_{4} \frac{d V_{C 4}}{d t}=I_{L 3}-I_{C_{O}}-I_{O}$

The currents $\mathrm{I}_{\mathrm{C} 2}$, $\mathrm{I}_{\mathrm{C} 3}$, $\mathrm{I}_{\mathrm{Co}}$ are nothing but $C_{2} \frac{d V_{C 2}}{d t} \quad C_{3} \frac{d V_{C 3}}{d t}, C_{O} \frac{d V_{C_{O}}}{d t}$ are the average current flowing through respective capacitors like $\mathrm{C}_{2}, \mathrm{C}_{3}, \mathrm{C}_{0}$ at time of switch ' $\mathrm{S}$ ' is in OFF position. 


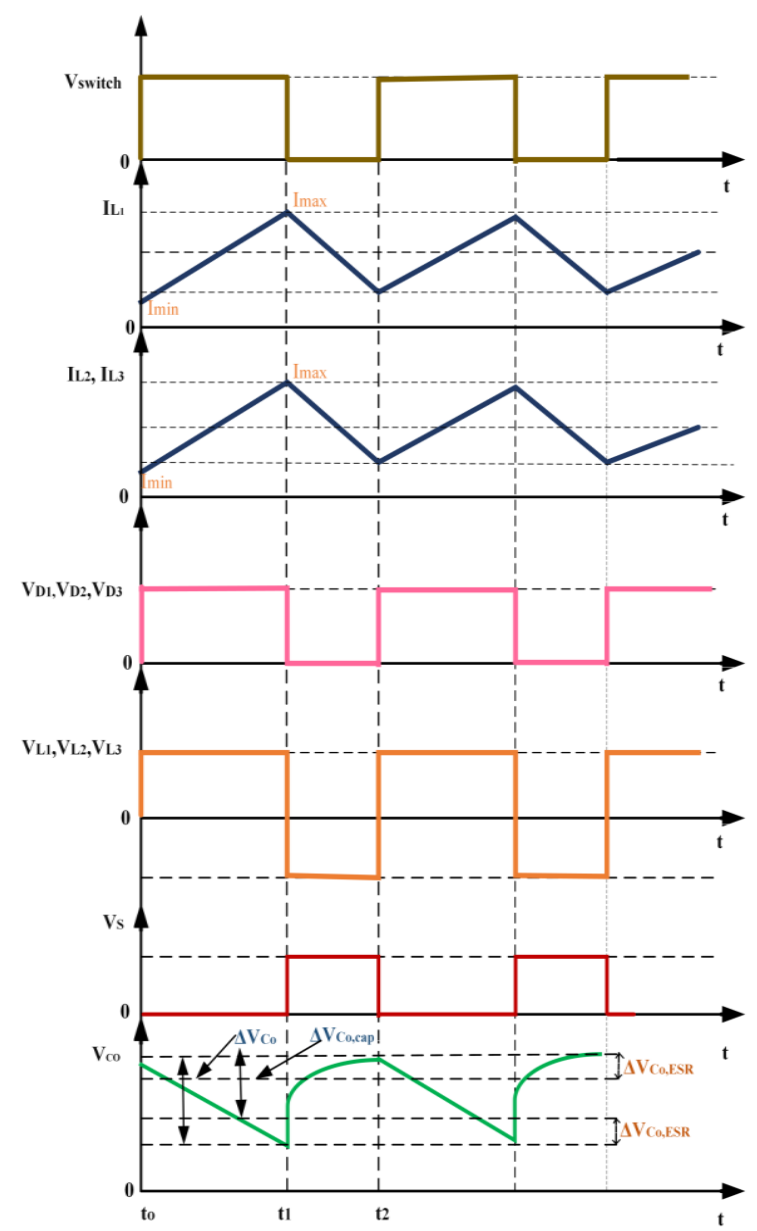

Fig. 4 Theoretical waveforms of designed converter

In direction to get the values of energy storage elements and other important parameters the equations can be solved from mode I and mode II by applying Volt-Sec balance method. By considering the mode I eq (7), (8) and (9) and mode II eq (15), (16) and (17) in both switch is ON and OFF positions of $\mathrm{L}_{1}, \mathrm{~L}_{2}, \mathrm{~L}_{3}$. By solving this we will get the capacitor's voltages $\mathrm{C}_{1}, \mathrm{C}_{2}, \mathrm{C}_{3}$ and $\mathrm{C}_{4}$ can be achieved as monitors.

$V_{C 1}=\frac{2 M V_{P V}}{1-M}=V_{C 4}$

$V_{C 2}=\frac{M V_{p v}}{1-M}=V_{C 3}$

Using equations (20) and (21), the voltage conversion ratio (K $\left.\mathrm{K}_{\mathrm{CCM}}\right)$, 'is attained as follows,

$K_{C C M}=\frac{V_{o}}{V_{p v}}=\frac{V_{C 3}+V_{C 4}}{V_{p v}}=\frac{3 M}{1-M}$

Where ' $\mathrm{M}$ ' is represents as duty cycle.

The Voltage conversion ratio at DCM $\left(\mathrm{K}_{\mathrm{DCM}}\right)$ is achieved as follows:

$$
K_{D C M}=\frac{M}{\sqrt{\tau_{L}}} \quad \text { (23) Where } \tau_{L}=\frac{2 L_{e}}{R T_{s}}
$$

The design of the converter for $120 \mathrm{Watts}$ at Boost mode and 30Watts at Buck mode of solar basedd LED lighting system with INC MPPT controller as shown in Table 1 . The important passive elements in the circuit can be calculated by using the equations written below.

$$
\begin{gathered}
L_{1,2,3}=\frac{V_{p v}}{\Delta I_{L_{1,2,3}} f_{s}} M \\
C_{1,2,3,4, o}=\frac{V_{O} T_{s}}{R \Delta V_{\operatorname{cap}\left(C_{1,2,3,4, o}\right)}} M
\end{gathered}
$$

Where $\Delta \mathrm{V}_{\mathrm{C}}$ is voltage ripple of the respective capacitor and this will produced from the current passing over the Equivalent series resistance (ESR) and the total charging and discharging of the respective capacitors can be expressed as follows.

$$
\begin{aligned}
& \Delta \mathrm{V}_{\mathrm{C} 1,2,3,4 \mathrm{o}}=\Delta \mathrm{V}_{\operatorname{ESR}\left(\mathrm{C}_{1,2,3,4, \mathrm{o}}\right)}+\Delta \mathrm{V}_{\mathrm{cap}\left(\mathrm{C}_{1,2,3,4, \mathrm{o}}\right)} \\
& \Delta V_{\operatorname{ESR}\left(C_{1,2,3,4, \mathrm{o}}\right)}=\frac{I_{O} \operatorname{ESR}\left(C_{1,2,3,4, \mathrm{o}}\right)}{1-M} \\
& \operatorname{ESR}\left(C_{1,2,3,4, o}\right)={ }^{\operatorname{Tan} \delta(C) / 2 \Pi f_{s}}
\end{aligned}
$$

The switching frequency $\left(f_{s}\right)$ of the presented converter is 33 $\mathrm{kHz}$. The ripple current of inductor $\Delta \mathrm{I}_{\mathrm{L}}$ and the output ripple voltage for the capacitor $\Delta \mathrm{V}_{\mathrm{C}}$ are usually considered as $20 \%$ and $10 \%$ respectively.

Table 1 Specifications of the proposed converter

\begin{tabular}{ccc}
\hline Parameters & Boost & Buck \\
\hline Output power $\left(\mathrm{P}_{\text {out }}\right)$ & $120 \mathrm{Watts}$ & $30 \mathrm{Watts}$ \\
Solar PV Voltage & $12 \mathrm{~V}$ & $24 \mathrm{~V}$ \\
Switching frequency & $33 \mathrm{kHz}$ & $37 \mathrm{kHz}$ \\
$\mathrm{L}_{1}$ & $100 \mu \mathrm{H}$ & $1 \mathrm{mH}$ \\
$\mathrm{L}_{2}, \mathrm{~L}_{3}$ & $260 \mu \mathrm{H}$ & $580 \mu \mathrm{H}$ \\
$\mathrm{C}_{1}, \mathrm{C}_{2}, \mathrm{C}_{3}, \mathrm{C}_{4}$ & $100 \mu \mathrm{F}$ & $100 \mu \mathrm{H}$ \\
$\mathrm{C}_{0}$ & $470 \mu \mathrm{F}$ & $470 \mu \mathrm{H}$ \\
Output current & $2.5 \mathrm{~A}$ & $2.5 \mathrm{~A}$ \\
Output Voltage & $48 \mathrm{~V}$ & $12 \mathrm{~V}$ \\
\hline
\end{tabular}

\section{ABOUT EFFICIENT MPPT CONTROLLER}

The incremental conductance MPPT control algorithm was designed based on curve obtained from P-V characteristics [26]. This efficient algorithm established in 1993 to overcome some drawbacks faced by P\&O algorithm. Incremental conductance algorithm is used to improve time of tracking and to generate more electrical energy from variable irradiation and different temperatures occurred by the environment. The calculation of extreme power point by using the curve between $\mathrm{dI} / \mathrm{dV}$ and $-\mathrm{I} / \mathrm{V}$. The position of the extreme power point is lies on the right side while the value of $\mathrm{dP} / \mathrm{dV}$ is negative and the position of extreme power point is lies on the left side when the value of $\mathrm{dP} / \mathrm{dV}$ is positive. The mathematical expression for incremental conductance method is written as follows

$\mathrm{P}=\mathrm{VI}$

Differentiating the above equation with respect to voltage then we get,

$$
\frac{d P}{d V}=\frac{d(I \times V)}{d V}=\left(V \times \frac{d I}{d V}+I \times \frac{d V}{d V}\right)=\left(V \frac{d I}{d V}+I\right)
$$

If value of slope $\frac{d P}{d V}$ is zero then automatically the maximum power point is reached. 
Substitute the value $\frac{d P}{d V}=0$ in above equation then

$\frac{d P}{d V}=\left(V \frac{d I}{d V}+I\right)$

From this equation we get

$$
\frac{d I}{d V}=-\frac{I}{V}
$$

For suppose MPP lies curve at right side i.e., dI/dV<-I/V then the voltage of PV necessity to decrease in order to meet the MPP [27]. This method used to describe the value of MPP, diminish the power loss and price of the system and improve the effectiveness. The implementation of Incremental conductance controller produced more stability for the system associated to $\mathrm{P} \& \mathrm{O}$ algorithm. The oscillations about the area of MPP can be inhibited and the time of tracking the extreme power point still not yet fast since the increment and decrement of voltages has been nominated manually by trial and error in this controller as presented in Fig.5.

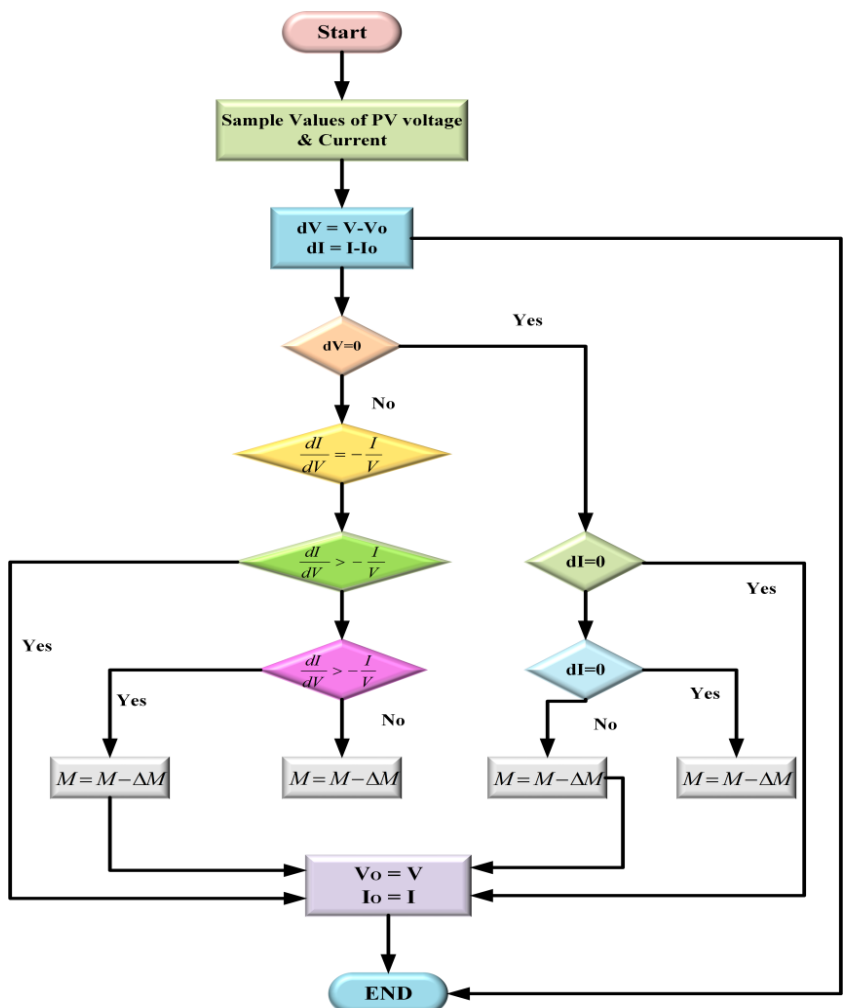

Fig. 5 Flowchart for Incremental conductance MPPT control

\section{DESIGN OF LED LIGHTING LOAD}

\section{A. Boost mode of Operation}

The well-known fact that an LED lamp turn ON with enough forward voltage $\left(\mathrm{V}_{\mathrm{F}}\right)$ and regulated forward current $\left(\mathrm{I}_{\mathrm{F}}\right.$ ) flowing through suitable resistance. White bright LED is chosen that $\mathrm{V}_{\mathrm{F}}$ is $3.5 \mathrm{~V}$ and $\mathrm{I}_{\mathrm{F}} 20 \mathrm{~mA}$ with suitable resistance of $270 \Omega$ is. Here we need to select 120 LEDs for 120 Watts of LED lamp arranged $12 \times 10$ array format. The LED array is rated by the selected voltage and current i.e., $48 \mathrm{~V}$ and $2.5 \mathrm{~A}$ respectively chosen for boost mode of operation and load as exposed in Fig.6 (a).

\section{B. Buck Mode of Operation}

Red LED is chosen that $V_{F}$ is $1.5 \mathrm{~V}$ and $\mathrm{I}_{\mathrm{F}} 25 \mathrm{~mA}$ with suitable resistance of $1 \Omega$ is. Here we need to select 80 LEDs for 30Watts of LED lamp arranged in $8 \times 10$ array format. The LED array is rated by the selected voltage and current i.e. $12 \mathrm{~V}$ and 2.5A respectively chosen for buck mode of process and the load is presented in Fig.6(b).

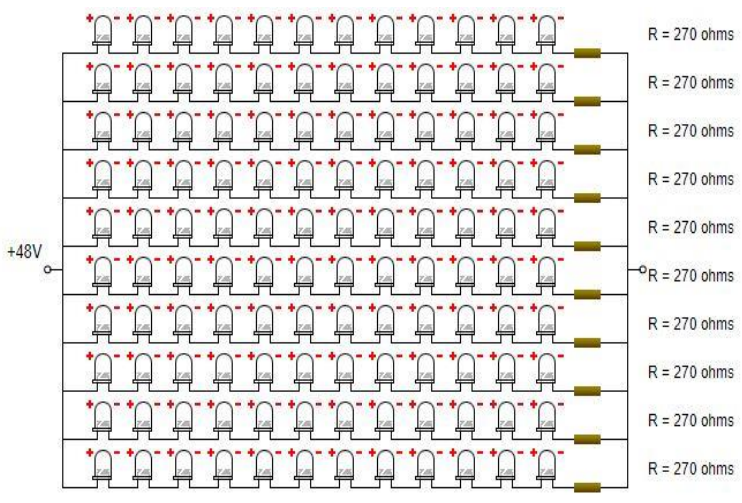

Fig. 6(a) LED load for Boost mode

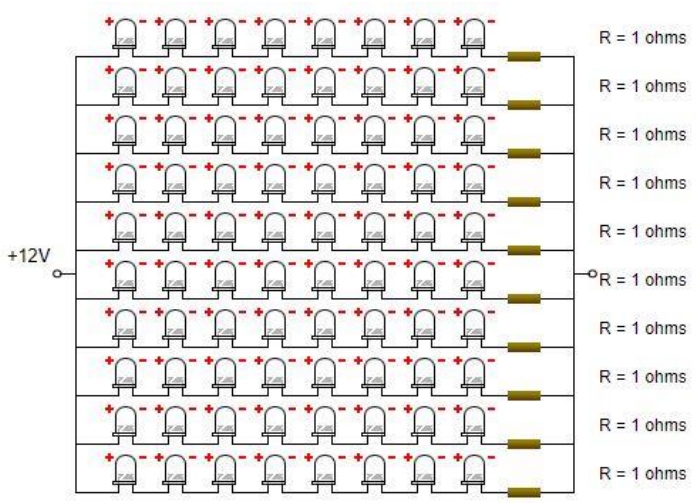

Fig. 6(b) LED load for Buck mode

\section{RESUlts AND Discussions}

The proposed topology is well designed and tested in the buck and boost modes of operations with efficient incremental conductance MPPT controller at constant and variable irradiance conditions to give efficient output for applications of solar LED lighting. To validate the performance of the presented configuration with INC MPPT controller for PV system developed at constant irradiation level i.e., at $1000 \mathrm{~W} / \mathrm{m}^{2}$ and variable irradiance is from (600$1000 \mathrm{~W} / \mathrm{m}^{2}$ ). In the boost mode of operation, the output voltage is equal to $47.65 \mathrm{~V}$. The output current and power values are equivalent to $2.482 \mathrm{~A} \& 118.2 \mathrm{~W}$ atts respectively as depicted in fig.7. The power is improved with increasing solar irradiance and the point to be noted that even in variation in power but the voltage i.e., $V_{\text {mpp }}$ is almost constant. In boost mode, the converter can effectively track the maximum power with high efficiency.

Fig.8 has shown the output voltage $11.8 \mathrm{~V}$ and output current 2.45A for the buck mode process of the configuration. In this mode also tracking the power $29 \mathrm{~W}$ is almost to be maximum at highest efficiency. The buck-boost topology is capable to track the power at variable irradiation with high gain as shown in fig.9 and fig.10 for boost and buck modes of operations respectively. 

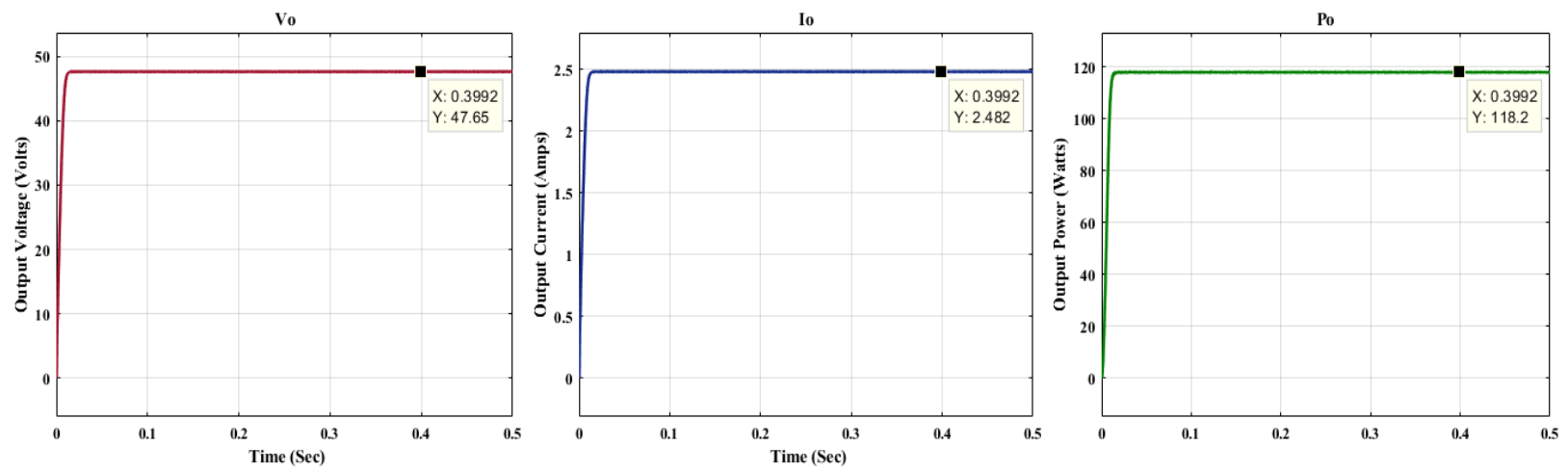

Fig. 7 Boost output waveforms of proposed structure such as voltage, current and power with INC MPPT controller at constant irradiance
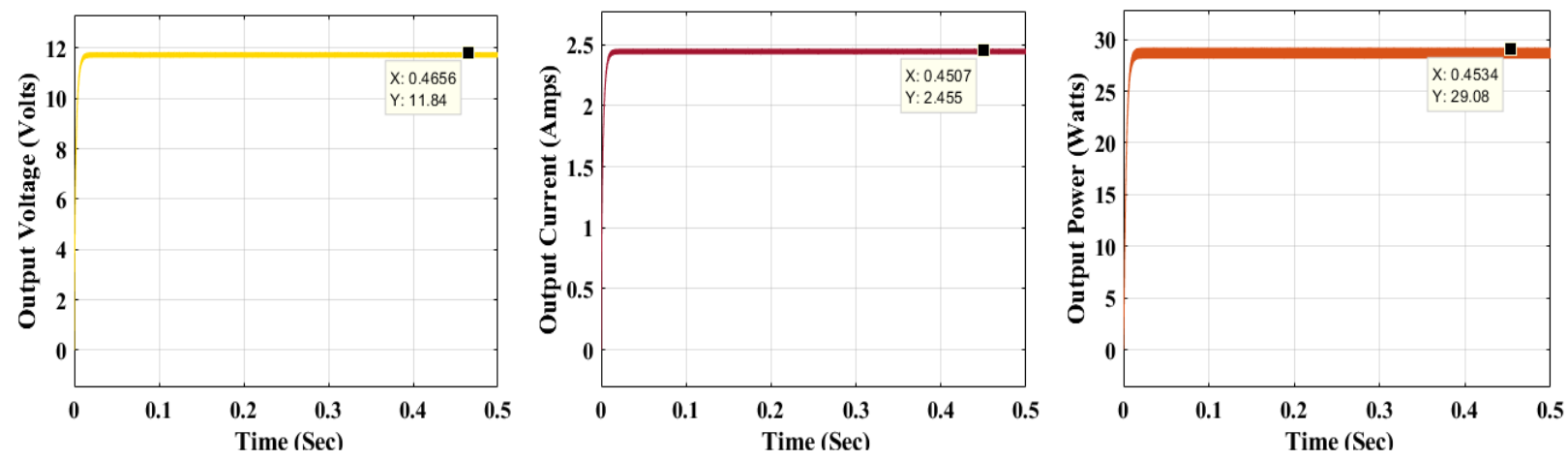

Fig. 8 Boost output waveforms of proposed structure such as voltage, current and power with INC MPPT controller at constant irradiance
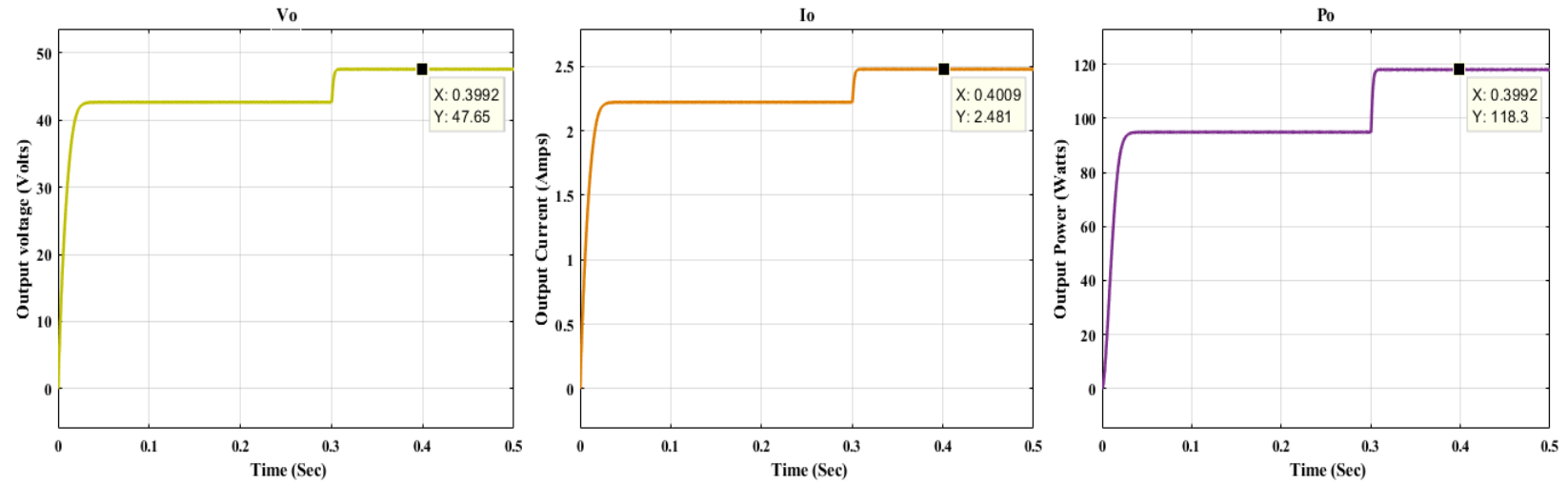

Fig. 9 Buck output waveforms of proposed topology such as voltage, current and power with INC MPPT controller at variable irradiance
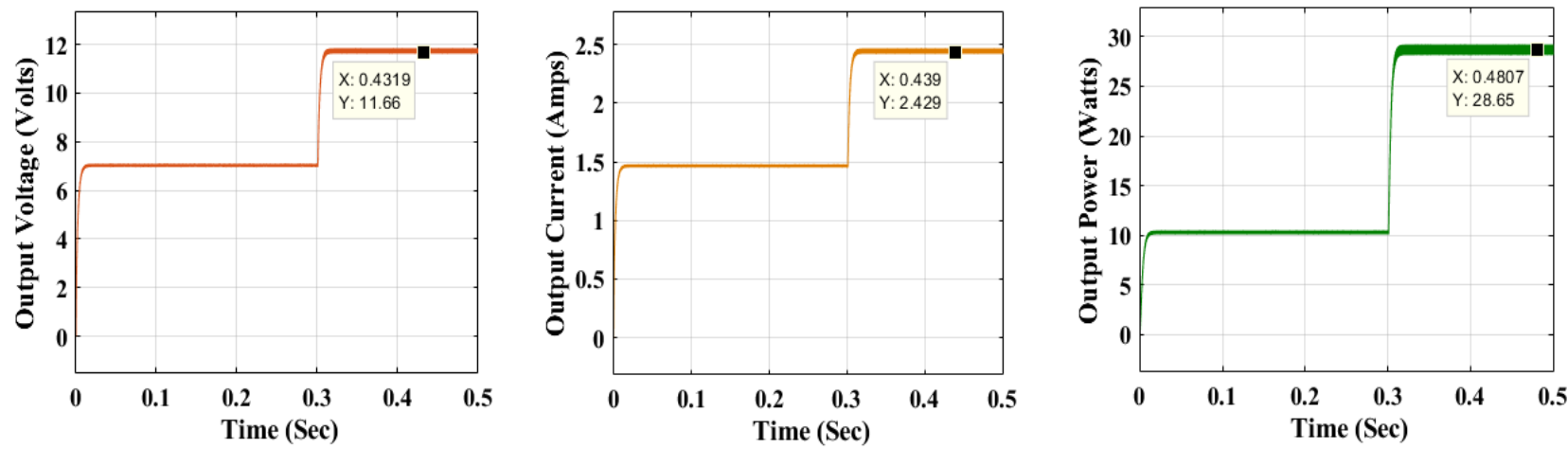

Fig.10. Buck output waveforms of proposed topology such as voltage, current and power with INC MPPT controller at variable irradiance 
In order to have a comparison between existing, proposed buck boost structure as shown in Table 2. Including the gain voltage, number of elements count, voltage stress and ripple voltage of the both converters are presented. According to the fig.11(a-c) it can be declare that the presented converter has the high gain voltage at lower duty cycle with reduced ripples.

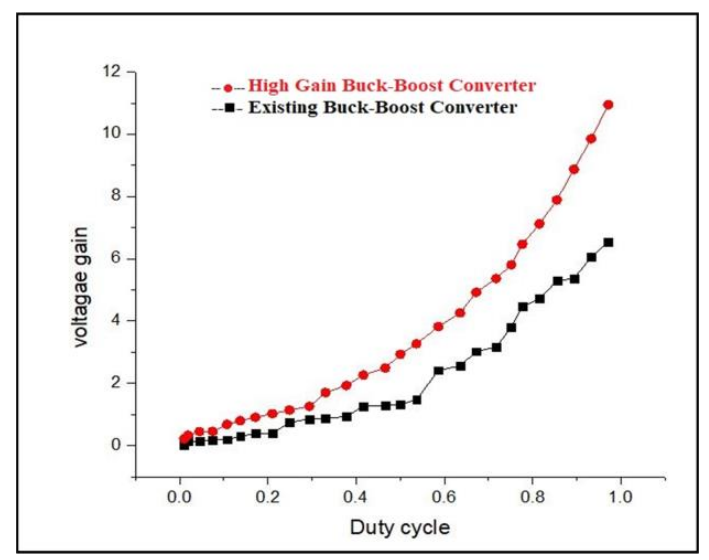

Fig. 11(a) voltage gain versus duty cycle

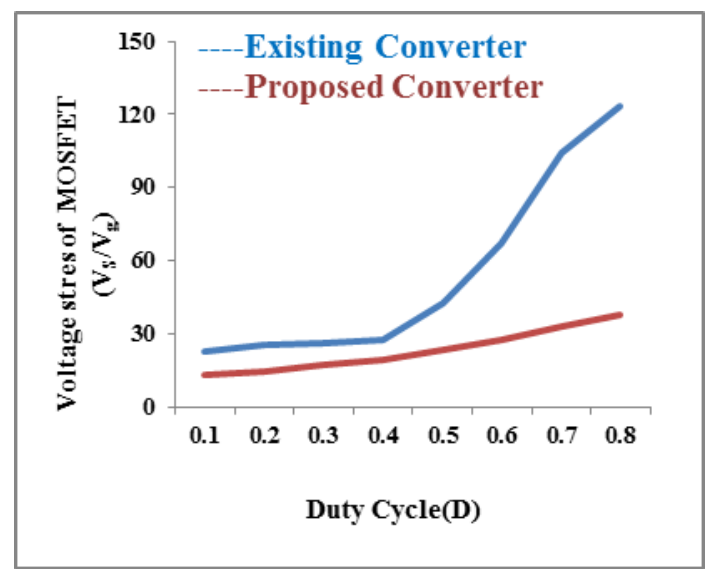

Fig. 11(b) Volatge stress versus dutycycle

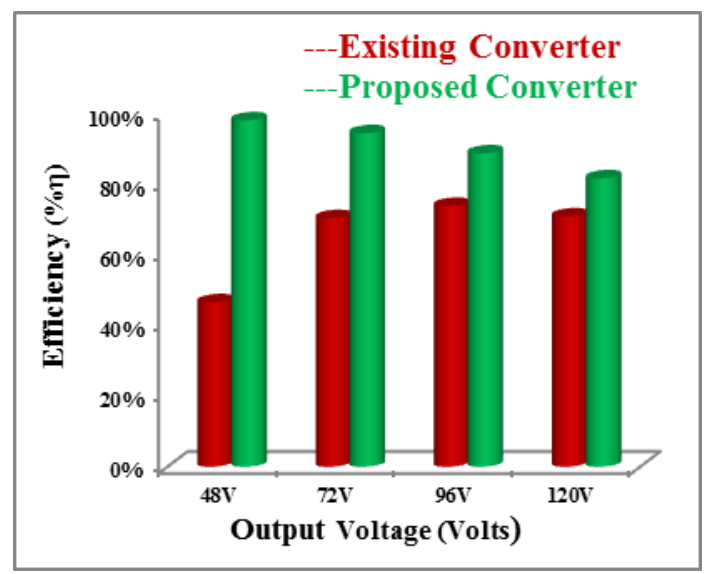

Fig. 11(c) Output voltage versus efficiency

The duty cycle of configuration is very low for both selected mode of operation. The competence of the topology about 98\%., the current \& voltage ripples are very less. Fig.11(a) evidently displays that the gain voltage of the projected topology is high at each duty cycle related to existing topology. Fig.11(b) clearly explains the voltage stress and ripple content of the proposed structure is less than that of the existing configuration. The curves presented in
Fig.11(c) observed that the efficacy of the proposed structure with output voltage is extremely high related to the existing one. The determined competence of proposed structure is about $97 \%$.

\section{CONCLUSION}

Solar based LED lighting system is designed with high gain buck-boost topology controlled by incremental conductance MPPT controller is analyzed and simulated. The model is simulated for two modes of operations buck and boost and the results obtained. These results of the simulation enlighten the performance of the converter with MPPT incremental conductance algorithm can be tracked the maximum power quickly. It is proved clearly that by comparing the all characteristics of existing converter, the proposed converter is approximately 2-3 times greater than that of the compared converter. Switch and diode utilization factors are very high related to the existing converter. Therefore, it permits to select low rating power semiconductor components and which outcomes in low cost of the configuration. The effectiveness of the projected converter is high compared to the existing converter at all ratings of the voltages. The results of the output current and voltage makes more appropriate for the operation of solar powered LED lighting applications for $120 \mathrm{~W}$ and 30W.

\section{REFERENCES}

1. E.Koutroulis, K.Kalaitzakis, N.C.Voulgaris, "Development of a microcontroller based photovoltaic maximum power point tracking system", in IEEE Trans. on Power Electron., vol. 16, no. 1, pp. 46-54, 2001.

2. F.Blaabjerg, F.Iov, T.Kerekes, R.Teodorescu, "Trends in power electronics and control of renewable energy systems", in 14th Int Power Electron. \& Motion Control Conf., EPE-PEMC'10, K-1-K-19, 2010.

3. E. F. Schubert, Light-Emitting Diodes, 2nd ed CambridgeU.K.Cambridge Univ. Press, 2006.

C.DiLouie, Advanced Lighting Controls: Energy Savings, Productivity, Technology and Applications. Lilburn, GA: Fairmont Press, 2005.

5. J.M. Ho, \& C.C. Lou, "The Design and Implementation of Stand-Alone Solar Power LED Lighting Systems," Recent Researches in Circuits, Systems, Electronics, Control \& Signal Processing, Athens, Greece, pp. 66-69, 2011.

6. E.Koutroulis, K.Kalaitzakis, N.C.Voulgaris, "Development of a microcontroller based photovoltaic maximum power point tracking system", in IEEE Trans. on Power Electron., vol. 16, no. 1, pp. 46-54, 2001.

7. I. L. Azevedo, M. G. Morgan, and F. Morgan, "The transition to solid-state lighting," Proc.. IEEE, vol. 97, no. 3, pp. 481-510, Mar. 2009.

8. M. Wendt and J. W. Andriesse, "LEDs in real lighting applications: From niche markets to general lighting," in Proc. IEEE Ind. Appl. Soc., 2006,pp. 2601-2603.

9. Abdi, Sh, K. Afshar, N. Bigdeli, and S. Ahmadi. "A novel approach for robust maximum power point tracking of PEM fuel cell generator using sliding mode control approach." Int. Jou. Elec. Sci., pp. 4192-4209, 2012

10. Esram T, Chapman PL. "Comparison of photovoltaic array maximum power point tracking techniques." IEEE Trans Energy Conver., vol.22(2), pp.439-49, 2007

11. Saravanan S, Babu NR. "Maximum power point tracking algorithms for photovoltaic system-A review", Renew Sustain Energy Rev., vol. 57, pp. 192-204, 2016.

12. Ram JP, Rajasekar N, Miyatake M. "Design and overview of maximum power point tracking techniques in wind and solar photovoltaic systems: Renew Sustain Energy Rev., vol. 73, pp. 1138-1159, 2017. 
13. D. P. Hohm and M. E. Ropp, "Comparative Study of Maximum Power Point Tracking Algorithms" Progress in photovoltaics: research and applications, 2003;II :47-62.

14. P.Padmavathi and N.Sudhakar, et al.,"Solar Powered LED Lighting with High Gain Boost Converter," Journal of Green Engineering, Vol.8, Issue-3, 2018

15. M. Arias, A. Vazquez, and J. Sebastían, "An overview of the AC-DCand DC-DC converters for LED lighting applications," Autom. J. Control Meas. Electron. Comput. Commun., vol. 53, no. 2, pp. 156-172, May 2012.

16. Natarajan, Sudhakar, and Rajasekar Natarajan. "Effective Suppression of Conducted Electro Magnetic Interference in DC-DC Boost Converter Using Field Programmable Gate Array Based Chaotic Pulse Width Modulation Switching." Electric Power Components and Systems 42.5 (2014): 471-480.

17. H. C. Shu, "Design and analysis of a switched-capacitor-based step-up dc/dc converter with continuous input current," IEEE Trans. Circuits Syst. I, Fundam. Theory Appl., vol. 46, no. 6, pp. 722-730, Jun. 1999.

18. Y. P. Hsieh, J. F. Chen, T. J. Liang, and L. S. Yang, "Novel high step-up DC-DC converter with coupled-inductor and switched-capacitor techniques," IEEE Trans. Ind. Electron., vol. 59, no. 2, pp. 998-1007,Feb. 2012.

19. T.-J. Liang and J.-H. Lee, "Novel-high-conversion-ratio high efficiency isolated bidirectional DC-DC converter," IEEE Trans. Ind.Electron.,vol. 62 , no. 7 , pp. 4492-4503, Jul. 2015.

20. K. I. Hwu and W.Z. Jiang, "Isolated step-up converter based on flyback converter and charge pumps," IET Power Electron., vol. 7, no. 9, pp. 2250-2257, Sep. 2014.

21. K. I. Hwu and T. J. Peng, "A novel buck boost converter combining KY and buck converters," IEEE Trans. Power Electron., vol. 27 , no. 5,pp. 2236-2241, May 2012.

22. Pandiarajan N, Muthu R (2011) Mathematical modeling of photovoltaic module with Simulink. International Conference on Electrical Energy Systems (ICEES 2011), p6.

23. Tu H-LT, Su Y-J (2008) Development of generalized photovoltaic model using MATLAB/SIMULINK. Proc World Congr Eng Comput Sci 2008:6

24. Salmi T, Bouzguenda M, Gastli A, Masmoudi A (2012) Matlab/simulink based modelling of solar photovoltaic cell. Int $J$ Renew Energy Res 2(2):6

25. F.Thomas, Ninu J, K.Boby, " Comparative Study on single switch and quadratic buck-boost converters", International journal of Emerging trends and technology, 2017:50(2)

26. Mihnea Rosu Hamzescu, Sergiu Oprea" Practical Guide to Implementing Solar Panel MPPT Algorithms" Microchip Technology Inc., 2013.

27. David Sanz Morrales, "Maximum Power Point Tracking Algorithms for Photovoltaic Applications," School of Science and Technology, Aalto University, 2010.

\section{AUTHORS PROFILE}

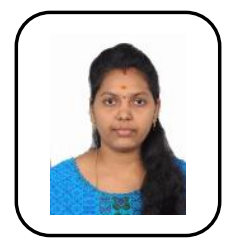

Pydikalva Padmavathi received the B.Tech degree in Electrical and Electronics engineering from Jawaharlal Nehru Technological University, Anantapuram, Andhrapradesh, India, in 2012, and the M.Tech degree in Power Electronics from the same University in 2014 She is currently pursuing towards the Ph.D degree with Vellore Institute of Technology, Vellore. Her research work focused in the field of power converters and LED lighting Drivers.

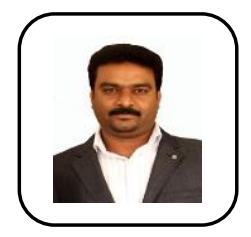

Sudhakar Natarajan received the B.E degree in Electrical and Electronics Engineering from Bharathiyar University, the M.Tech degree in in Electrical Drives and Control from Pondicherry University, and the Ph.D degree from VIT University. $\mathrm{He}$ is currently working as Associate Professor in School of Electrical Engineering, Vellore Institute of Technology, and Vellore. His research work focused in the area of EMI/EMC in power converters, Electrical Vehicles and LED Drivers. 